\title{
Dioxin emissions from municipal solid waste incinerators (MSWIs) in France
}

\author{
Ange Nzihou ${ }^{\mathrm{a}}$, Nickolas J. Themelis ${ }^{\mathrm{b}, *}$, Mohammed Kemiha ${ }^{\mathrm{a}}$, Yohan Benhamou ${ }^{\mathrm{b}}$ \\ ${ }^{a}$ Université de Toulouse, Ecole des Mines Albi, CNRS, Centre RAPSODEE, Campus Jarlard, F-81013 Albi, France \\ ${ }^{\mathrm{b}}$ Earth Engineering Center, Columbia University, 500 West 120th St., \#926, New York, NY 10027, USA
}

\begin{abstract}
A B S T R A C T
The objective of this study was to determine whether the fear of dioxin/furan emissions from waste-toenergy plants was justified by the 2007 status of emissions of French municipal solid waste incinerators (MSWIs). All emissions were examined, plant by plant, but this paper focuses on the incinerator emission that is most frequently mentioned in the French media, toxic dioxins and furans. The study showed that there are 85 large MSWI that generate electricity or heat, i.e., waste-to-energy (WTE) plants, and 39 smaller MSW incinerators. The results showed that all French MSWI are operated well below the EU and French standard of $0.1 \mathrm{ng} \mathrm{TEQ} \mathrm{Nm}{ }^{-3}$ (toxic equivalent nanograms per standard cubic meter) and that their total dioxin/furan emissions decreased from $435 \mathrm{~g}$ TEQ in 1997 to only $1.2 \mathrm{~g}$ in 2008 . All other industrial emissions of dioxins have also decreased and the major source is residential combustion of wood ( $320 \mathrm{~g} \mathrm{TEQ}$ ). It was extremely difficult to obtain MSWI emission data. This unwarranted lack of transparency has resulted in the public perception that MSWI plants are major contributors to dioxin emissions while in fact they have ceased to be so.
\end{abstract}

Keywords:

Waste-to-energy

WTE

Incinerators

France

Dioxins

Furans

Emissions

Grenelle

Municipal solid waste

MSW

Combustion

Waste management

Hierarchy

\section{Introduction}

In recent years, incineration and combustion of solid waste has become one of the most widely used alternatives for waste management. This process is considered by regulators as a strategic option for waste reduction and disposal (Richter and Johnke, 2004; Kollikkathara et al., 2009). In comparison with other waste treatments, incineration presents advantages such as volume reduction, energy recovery, and elimination of pathogen agents. However, the public opinion of most developed countries is frequently concerned about the installation of municipal, hazardous, and medical waste incinerators (Domingo, 2002; Singh and Prakash, 2007).

Although dioxins are generally produced in many combustion processes (Kulkarni et al., 2008), until a few years ago, incinerators have traditionally been pointed out as one of the most important sources of toxic emissions, not only dioxins but also heavy metals (Wang et al., 2009; Kim et al., 2008; Shibamoto et al., 2007; Quass et al., 2004). There are many other industrial (cement kilns and power plants) and diffuse (vehicle emissions, domestic coal/wood combustion and natural fires) sources also emitting these pollutants (Mari and Domingo, 2010). Among the pollutants emitted

\footnotetext{
* Corresponding author. Tel.: +1 212854 2138; fax: +1 2128547081.

E-mail address: njt1@columbia.edu (N.J. Themelis).
}

by waste incinerators, dioxins have generated a lot of controversies mainly because they are among the most toxic environmental compounds (Schuhmacher and Domingo, 2006).

A report released for public comment in 1994 by the US Environmental Protection Agency (Brunner, 1994; USEPA, 2012) describes dioxin as a serious public health threat in the 1960s. Dioxins, as they are commonly called, are polychlorinated dibenzo-p-dioxins (PCDDs) and polychlorinated dibenzofurans (PCDFs) compounds with similar chemical properties.

Dioxins were first detected in municipal solid waste incinerator (MSWI) emissions in the 1970s in the Netherlands (Olie et al., 1977). Due to their notable toxic properties (Schecter et al., 2006), they have received prolonged attention by environmental regulators and the scientific community (Viel et al., 2011; Floret et al. 2007).

The major identified sources of environmental release have been grouped into four major categories: incineration sources, combustion sources, industrial sources and reservoir sources (Kulkarni et al., 2008). The toxicity equivalence quantity (TEQ) values express and evaluate generally the dioxins emission toxicity. It is correlated with the amount of chlorine content in the samples and the amount of dioxin formed in exhaust gases from an incinerator. When the same sample was incinerated at different temperatures, however, the sample burned at low temperature yielded a 
higher TEQ value than did the sample burned at high temperature. The samples that did not contain chlorine or were not combusted with chlorides exhibited low TEQ values (Shibamoto et al., 2007). In contrast, samples with high chlorine content, such as PVC (51.3\%), gave high TEQ values.

It was also observed that several past studies demonstrated the presence of significant quantities of dioxins and dioxin precursors in municipal solid waste, in the order of $50 \mathrm{ng} \mathrm{I}-\mathrm{TEQ} / \mathrm{kg}$ (Abad et al., 2002).

The composition of dioxins in the flue gases exiting the combustion chamber of incinerators ranges from 1 to $500 \mathrm{ng} \mathrm{TEQ} \mathrm{Nm}^{-3}$. Therefore, it is important to treat the flue gas to reduce its concentration to an acceptable limit $\left(0.1 \mathrm{ng}\right.$ TEQ $\left.\mathrm{Nm}^{-3}\right)$ before releasing to the environment (Kulkarni et al., 2008). In that context, ambient air monitoring is an essential issue to estimate pollutant emissions such as dioxins and mercury.

Intensive studies have been conducted on various dioxin emission sources, including waste combustion sources, chemical-industrial sources, and other thermal sources (Mari and Domingo, 2010). Although incineration is an effective way of treating post-recycling municipal solid waste (MSW), health effects associated with stack emissions remain a major public concern. Some toxics, either present in waste or formed during the process, may escape pollution control devices and released to the atmosphere (Cangialosi et al., 2008). In 1998, the French Ministry of Environment revealed that dioxin emissions from the MSW incinerator at Besançon (France) were $16.3 \mathrm{ng} \mathrm{TEQ} \mathrm{Nm}{ }^{-3}$, whereas the European guide value is $0.1 \mathrm{ng} \mathrm{I}^{-T E Q ~ \mathrm{Nm}^{3}}$ (Viel et al., 2011; Floret et al. 2007).

Studies by Floret et al. (2007) and Viel et al. (2011) examined in details the nature of dioxins soil contamination in the surrounding area of the Besancon incinerator to determine whether more than one potential emission source could explain the presence of the dioxins in soils. However, the sampling site selection process, the high similarities in the congener profiles, and the absence of other polluting industries in the area resulted in conclusion that the presence of dioxins in the area was solely due to the MSW incinerator. Therefore, since the most polluting furnaces have been shut down and replaced by a new furnace equipped with a modern Air Pollution Control systems, slowly decreasing dioxin concentration in soils are to be expected in the study area.

Technology advances in Air Pollution Control systems, in particular the injection of activated carbon and the replacement of electrostatic precipitators (ESPs) by fabric bag filters the past 15 years have decreased the levels of dioxins in the flue gas so dramatically, that they are difficult to measure. Also, very stringent systems have been put in place in France, Spain and Italy to monitor and inventory dioxin emissions from all high temperature point sources (Porteous, 2005). The successful adoption of composting, recycling and energy recovery to form a unity of purpose in integrated waste management has been achieved in Continental Europe and Scandinavia (Porteous, 2005).

The recently approved EU Waste Framework Directive (2008/ 98/EC) seeks reducing the percentage of MSW which is deposited in landfills. This is intended to promote prevention, recycling and energy recovery over landfilling, as required by the hierarchy of waste management (Fig. 1). Among these, waste incineration with energy recovery (waste-to-energy or WTE) has become a serious option in developed countries. It presents numerous advantages over landfilling, such as energy recovery, land conservation, volume minimization, and reducing greenhouse gas emissions. However, public controversy is still encountered at locations where municipal solid waste incinerators (MSWIs or WTE) are planned. Governments and health authorities are under increasing pressure from the public to ensure the absence of potential adverse health effects produced by all waste management practices (Giusti, 2009). As noted earlier, incinerators have been historically associ-

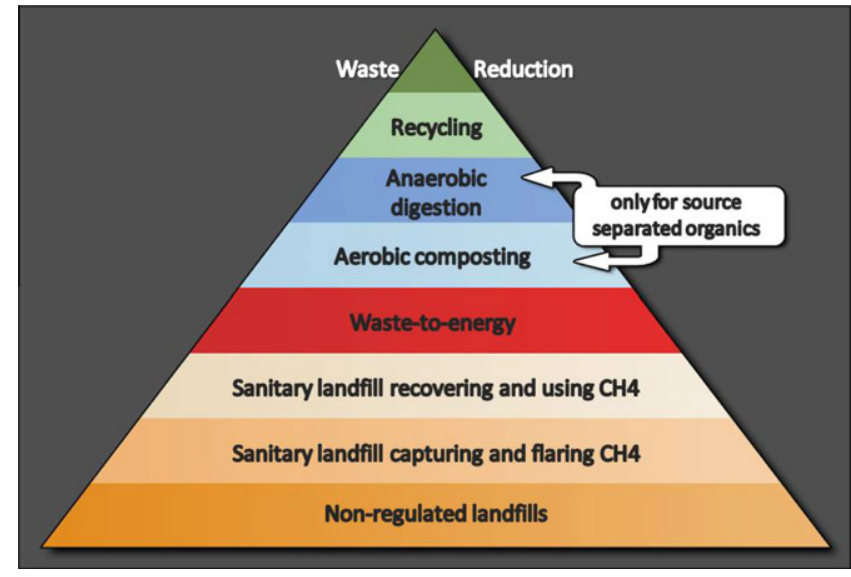

Fig. 1. The hierarchy of waste management (Kaufman and Themelis, 2009).

ated to emissions of toxic chemicals, such as dioxins, polychlorinated dibenzo-pdioxins and dibenzofurans (PCDD/Fs) and heavy metals (Cheng and $\mathrm{Hu}, 2010$ ), and the lack of communication and transparency of modern incinerator emission data has led to the unfavorable opinion on WTE plants.

Environmental legislation is becoming increasingly restrictive, and consequently industrial plants have to be constantly adapted to lower gas emissions. In particular, WTE plants built and operated to meet the mandatory EU Waste Incineration Directive standards, such as the new Isseane WTE in Paris, are an extremely lowrisk, environmentally-benign method of managing post-recycling/ composting MSW instead of landfilling it. A number of recent studies have demonstrated that emissions of toxic pollutants from modern MSWI plants have a relatively low environmental impact in comparison to other alternatives of waste disposal or to other industrial activities (Domingo, 2002; Kao et al., 2007).

Human exposure to dioxins mainly occurs via food consumption, and more specifically through the ingestion of fatty foodstuffs (Domingo and Bocio, 2007), but also by means of inhalation (Nadal et al., 2004).

Industrial plants differ significantly in the flue gas treatment technology, the energy recovery equipment and the year of construction. Grosso et al. (2007) had compared emissions of three plants (old technology and partially upgraded plant with flue gas treatment system) representative of state-of-the-art MSW incinerators in Europe. There results showed that release is influenced by furnace dioxins net production or destruction capacities of the plants examined are essentially dependent on operating conditions maintained along flue gas pathway where potential de novo synthesis or memory effects might occur, as well as on the presence of removal options based on phase transfer (solid sorption, liquid absorption through condensation effects) rather than on conversion processes (catalytic oxidation inside SCR reactors).

Emissions of dioxin toxic contaminants are believed to have reduced in some industrial countries and there are suggestive data indicating that background levels in human blood and milk in Germany, the Netherlands, and United States have declined, recently. (Kulkarni et al. 2008).

A recent study by Vilavert et al. (2011) compared concentrations of volatile organic compounds and bioaerosols in the vicinity of the MSWI plant in Tarragona (Spain) with reference values. The results showed that the MSWI had no influence on the chemical and microbiological pollution in the surrounding environment.

On the basis of the calculations of Cangialosi et al. (2008), one may conclude that health risks due to the emissions from a properly equipped and operated modern MSWI have relatively small health significance for the surrounding population. The average 
concentration in the Taranto (Italy) MSWI stack gas was about $0.006 \mathrm{ng} \mathrm{TEQ} \mathrm{Nm}{ }^{-3}$ of dioxins, i.e., only $6 \%$ of the EU standard for dioxins. Clearly, the strategies to reduce dioxin emissions to air developed by the EU member states and the Commission have achieved appreciable success.

\section{Case study and disposition of MSW in France}

France has a population of about 63 million and generates 34 million tons of MSW annually (ADEME, 2009). According to Eurostat statistics (Fig. 2), 18\% of the French MSW is recycled, $15 \%$ is composted, $32 \%$ is incinerated and $36 \%$ is landfilled. There are 110 incinerators that produce electricity and/or district heating (waste to energy or WTE plants) out of about 125 incinerators.

In October 2007, the government of France convened the «Grenelle Environnement» that brought together politicians, professional organizations, and NGOs to consider how to deal with present and future environmental challenges (Grenelle 2007). With regard to waste management, the first goal of the Grenelle was waste reduction and increased recycling. The second goal was clear reduction in the health and environmental impacts of waste management policies. The third goal was to raise awareness and (provide) information to the French citizens. The fourth and final goal of Le Grenelle dealt with incineration. It consisted of the statement that the place of incineration in the politics of waste management in France has been a source of long debates but there are still widely divergent positions. A significant decrease in the quantities incinerated is desired by some groups; this decrease should be reflected... in a halt in new incineration projects". In summary, the Grenelle did not indicate that WTE is an environmentally superior technology to landfilling; it is interesting to note that despite the Grenelle, one of the most important WTE plants in the world, the Isseane-TIRU plant in Paris, started operations in 2008 on the bank of Seine River and a few kilometers from the Eiffel Tower.

The objective of this study by Columbia University and the Ecole des Mines Albi was to determine whether this fear of incineration was justified by the current status of emissions of French WTE facilities. All WTE emissions were examined, plant by plant, but this paper focuses on the incinerator emission that is most feared and, also, exists in stack gas in extremely low concentrations: dioxins.

\section{Results}

\subsection{Dioxin emission of French MSW incinerators in 2008}

Using the «master spreadsheet» of the Ministry of Ecology (MEDDTL, 2008) and published information (Quass et al. 2004; Benhamou, 2010) on the nominal capacities of existing incinerators in France, the authors constructed the data presented in Tables 1 and 2. A plant-by-plant investigation showed clearly that by 2008 , all 124 MSW incinerators performed much better than the 2008 French standard for dioxin emissions: The average 2008 dioxin emission of the 85 largest WTE plants in France (Table 1) was 0.017 ng TEQ of

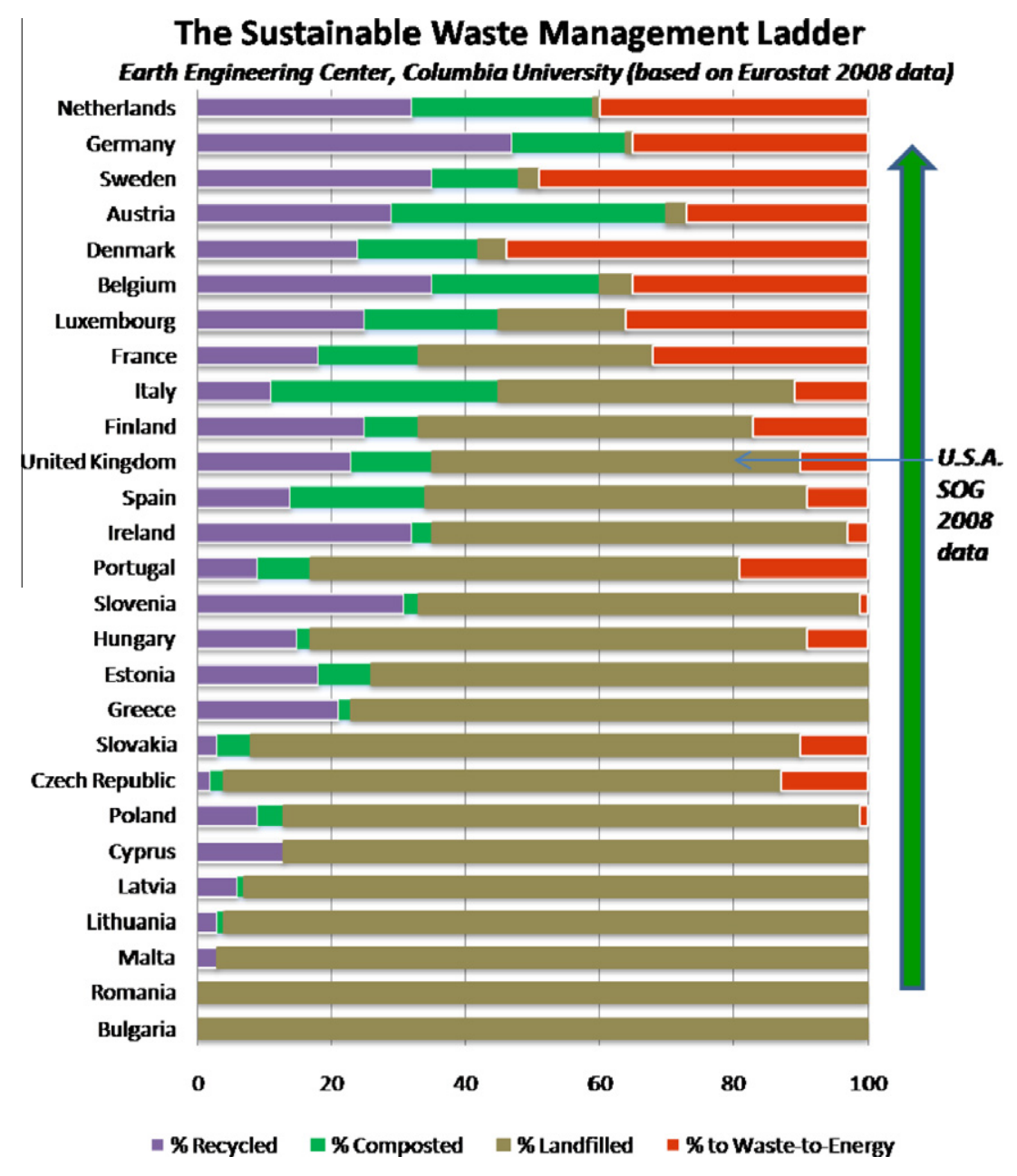

Fig. 2. Disposition of MSW in the European Union (Eurostat 2008 data). 
Table 1

Capacities and dioxin emissions of the larger MSW incinerators in France.

\begin{tabular}{ll}
\hline Number of plants & 85 \\
Total WTE capacity (at 90\% plant availability) & 14.0 million tons/ \\
& year \\
& $0.017 \mathrm{ng} \mathrm{TEQ} \mathrm{Nm}^{-3}$ \\
Average concentration of dioxins in stack gas & $0.1 \mathrm{ng} \mathrm{TEQ} \mathrm{Nm}^{-3}$ \\
EU and French standard & $17 \%$ \\
Plant emission as \% of dioxin standard & $1.19 \mathrm{~g} \mathrm{TEQ}$ \\
Estimated * total emission of dioxins per year N.B. & \\
$\mathrm{Nm}^{3}=(0.017 * 5000 * 14.0 \mathrm{E} 6 / 1 \mathrm{E} 9)$ &
\end{tabular}

Table 2

Capacities and dioxin emissions of the smaller MSW incinerators in France.

\begin{tabular}{ll}
\hline Number of plants & 39 \\
Total WTE capacity (at 90\% plant availability) & 1.36 million tons \\
Average concentration of dioxins in stack gas & $0.003 \mathrm{ng} \mathrm{TEQ} \mathrm{Nm}^{-3}$ \\
EU and French standard & $0.1 \mathrm{ng} \mathrm{TEQ} \mathrm{Nm}^{-3}$ \\
Plant emission as \% of dioxin standard & $3 \%$ \\
Estimated total emission of dioxins per year N.B. & $0.02 \mathrm{~g} \mathrm{TEQ}$ \\
$\quad \mathrm{Nm}^{3}=\left(0.003^{*} 5000 * 1.36 \mathrm{E} 6 / 1 \mathrm{E} 9\right)$ & \\
\hline
\end{tabular}

dioxins per standard cubic meter of stack gas, that is only $17 \%$ of the French and international standard for dioxins. The annual capacity of each incinerator was calculated by multiplying the reported nominal capacity, in tons/hour, by an assumed operating time of $8000 \mathrm{~h}$ per year (i.e., about $91 \%$ plant availability).

As shown in Table 1, the nominal MSW capacity of the 85 larger incinerators or waste-to-energy (WTE) power plants in France was 14.0 million tons. Therefore, on the basis of the assumed average gas flow of 5000 standard cubic meters of dry stack gas per ton of MSW, the total 2008 dioxin emission of these 86 plants was $1.19 \mathrm{~g}$ of toxic equivalent dioxins. These incinerators ranged in capacity from 790,000 down to 60,000 tons per year. Table 2 shows the emissions of the 39 smaller incinerators that ranged from 60,000 down to 12,000 tons per year capacity. In this case, the average dioxin emission was even lower, at 0.003 ng TEQ per standard cubic meter of stack gas, i.e., 3\% of the French standard for dioxins. The total capacity of the smaller plants in Table 3 was 1.36 million tons and the calculated total 2008 dioxin emissions a miniscule $0.02 \mathrm{~g}$ of dioxins.

It is evident from Tables 1 and 2 that the French waste-to-energy plants (MSW incinerators) have become very efficient in controlling the most feared, and most difficult to control, emission of dioxins.

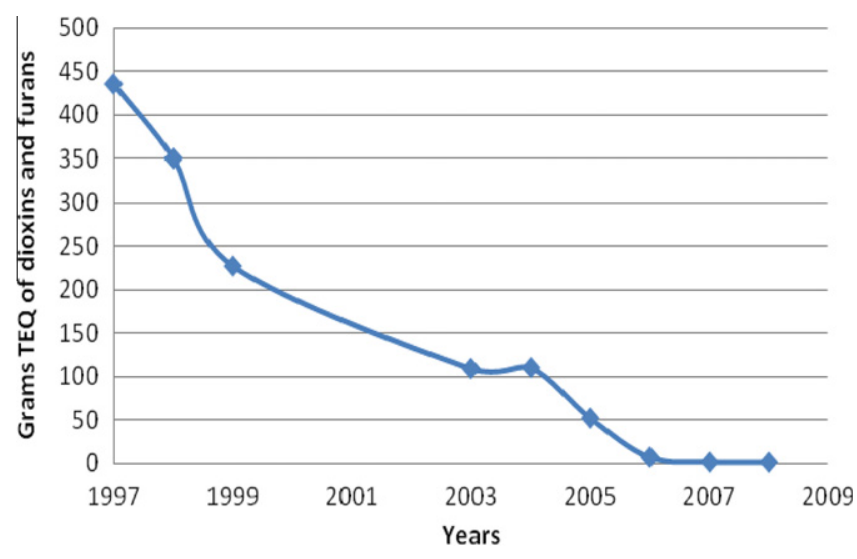

Fig. 3. Change in dioxin emissions of French MSW incinerators, 1997-2008.

\subsection{Change in dioxin emissions of French MSWI in recent years}

As noted earlier, France introduced the dioxin standard of $2 \mathrm{ng} \mathrm{TEQ} \mathrm{Nm} \mathrm{Nm}^{-3}$ in 1991 and the more stringent standard of $0.1 \mathrm{ng}$ TEQ Nm${ }^{-3}$ in 2002, that is several years later than northern European nations, the US, and Japan. Because of this, as late as 2001 the French MSW incinerators emitted a total of $150 \mathrm{~g}$ TEQ of dioxins (see Fig. 3 below). This amount was ten times higher than the 2001 dioxin emissions of US incinerators that combusted twice as much MSW (Table 3).

However, it must be noted that the $2 \mathrm{ng}$ TEQ Nm${ }^{-3}$ standard, that was in effect from 1991 to 2002, was about 50 times lower than the dioxin concentration in incinerator stack gas prior to the introduction of activated carbon injection and other modern gas control technology (estimated by the authors at about $100 \mathrm{ng} / \mathrm{Nm}^{3}$ ), that is before the dioxin problem was recognized universally. To determine the effect of the imposition of the lower dioxin standard in 2002, the authors used the "master» spreadsheet provided by the Ministry of Ecology of France and sorted out the dioxin emission data reported by all French MSW incinerators, for the years 2002-2008 (Fig. 3).

The horizontal lines in Fig. 4 show the French dioxin standard in the periods $1992-2002\left(2 \mathrm{ng} / \mathrm{Nm}^{3}\right)$ and since $2002\left(0.1 \mathrm{ng} / \mathrm{Nm}^{3}\right)$. The descending curve shows that the average dioxin emissions of all 124 incinerators in our study decreased rapidly after the $0.1 \mathrm{ng}$ standard was imposed in 2002.

Table 3

Decrease in US WTE emissions from 1987 to 2002 . $^{\text {a }}$

\begin{tabular}{|c|c|c|c|c|c|c|c|}
\hline Sources & 1987 & $\%$ Of total & 1995 & $\%$ Of total & 2002/2004 Estimate & $\%$ Of total & \% Reduction between 1987 and 2002 \\
\hline MSW & 8877 & 63.66 & 1250 & 38.52 & 12 & 1.09 & 99.86 \\
\hline Medical waste & 2.590 & 18.57 & 488 & 15.04 & 7 & 0.64 & 99.73 \\
\hline Sewage sludge & 6 & 0.04 & 14 & 0.43 & 14 & 1.27 & -133.33 \\
\hline Hazardous waste & 5 & 0.04 & 5 & 0.15 & 3 & 0.27 & 40.00 \\
\hline Total incineration & 11.478 & 82.31 & 1757 & 54.14 & 36 & 3.28 & 99.69 \\
\hline Backyard barrel burning & 604 & 4.33 & 628 & 19.35 & 628 & 57.14 & -3.97 \\
\hline Metal smelting & 955 & 6.85 & 301 & 9.28 & 35 & 3.18 & 96.34 \\
\hline Cement kilns & 131 & 0.94 & 173 & 5.33 & 25 & 2.27 & 80.92 \\
\hline Land applied sewage sludge & 76 & 0.54 & 76 & 2.34 & 76 & 6.92 & 0.00 \\
\hline Pulp and paper & 372 & 2.67 & 23 & 0.71 & 15 & 1.36 & 95.97 \\
\hline Coal fired utilities & 50 & 0.36 & 60 & 1.85 & 60 & 5.46 & -20.00 \\
\hline Industrial wood burning & 26 & 0.19 & 27 & 0.83 & 27 & 2.46 & -3.85 \\
\hline Residential wood burning & 89 & 0.64 & 62 & 1.91 & 62 & 5.64 & 30.34 \\
\hline Diesel trucks & 27 & 0.19 & 35 & 1.08 & 35 & 3.18 & -29.63 \\
\hline Other & 137 & 0.98 & 103 & 3.17 & 100 & 9.10 & 27.01 \\
\hline Total & 13,945 & 100.00 & 3245 & 100.00 & 1099 & 100.00 & 92.12 \\
\hline
\end{tabular}

\footnotetext{
${ }^{a}$ Emission expressed in g TEQ based on US EPA data (Deriziotis, 2004).
} 


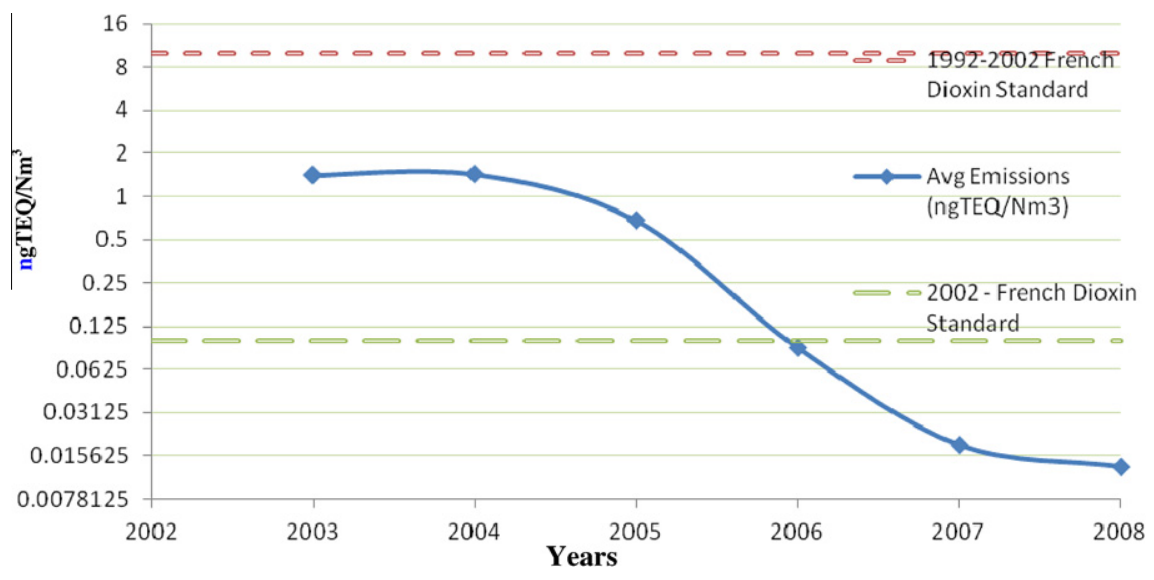

Fig. 4. Decrease in average dioxin emission of 124 French incinerators, 2003-2008.

\section{Conclusions}

In this study, the $124 \mathrm{MSW}$ incinerators in France were divided into two groups: 85 large MSWI that generate electricity or heat and are commonly known as waste-to-energy (WTE) plants; and 39 smaller MSW incinerators that do not export energy. The results showed that French MSWI dioxin/furan emissions decreased from $435 \mathrm{~g}$ in 1997, i.e. about 50\% of the dioxins emitted in France at that time, to only $1.2 \mathrm{~g}$ in 2008 . Therefore, even if it is assumed that all other point-source industrial emissions of dioxins were decreased to zero by the year 2008 , so that the only other source of dioxins was residential combustion of wood, estimated in the EU dioxin inventory to be about $320 \mathrm{~g}$ TEQ (Quass, 2005), the total MSWI emissions of dioxins amounted to only $0.37 \%$ of the total dioxin emissions in France. The study showed that all 124 French MSW incinerators are operated well below the EU and French standard.

Another finding of this study is that although all the MSW incinerators in France report dioxin emission to the local government authorities and through them to the Ministry of Ecology and Sustainable Development, these data were very difficult to locate and are not readily available to the public, except in isolated cases where a particular MSWI publishes such information on their web. It is believed that this unwarranted lack of transparency has resulted in the public perception that MSWI plants are major contributors to dioxin emissions while in fact they have ceased to be so.

\section{References}

Abad, E., Adrados, M.A., Caixach, J., Rivera, J., 2002. Dioxin abatement strategies and mass balance at a municipal waste management plant. Environ. Sci. Technol. 36, mass balan.

ADEME, 2009. Les Déchets en Chiffre, ADEME Edition 2009. <www.ademe.fr/>.

Benhamou, J., 2010. Comparison of Environmental Performance of Waste-to-Energy (WTE) Plants in France with Denmark and Germany. MS thesis, Columbia University.

Brunner, C.R., 1994. Hazardous Waste Incineration, second ed. McGraw-Hill, New York.

Cangialosi, F., Intini, G., Liberti, L., Notarnicola, M., Stellacci, P., 2008. Health risk assessment of air emissions from a municipal solid waste incineration plant - a case study. Waste Manage. (Oxford) 28, 885-895.

Cheng, H., Hu, Y., 2010. Curbing dioxin emissions from municipal solid waste incineration in China: re-thinking about management policies and practices. Environ. Pollut. 158, 2809-2814.

Deriziotis, P.G., 2004. Substance and Perceptions of Environmental Impacts of Dioxin Emissions. MS thesis. Earth Resources Engineering, Columbia University.

Domingo, J.L., 2002. Human health risks of dioxins for populations living near modern municipal solid waste incinerators. Rev. Environ. Health 17, 135147.

Domingo, J.L., Bocio, A., 2007. Levels of PCDD/PCDFs and PCBs in edible marine species and human intake: a literature review. Environ. Int. 33, 397-405.

Floret, N., Lucot, E., Badot, P.M., Mauny, F., Viel, J.F., 2007. A municipal solid waste incinerator as the single dominant point source of PCDD/Fs in an area of increased non-Hodgkin's lymphoma incidence. Chemosphere 68, 1419-1426.
Giusti, L., 2009. A review of waste management practices and their impact on human health. Waste Manage. 29, 2227-2239.

Grenelle, 2007. <http://www.legrenelle-environnement.fr/-Version-anglaise.html>.

Grosso, M., Cernuschi, S., Giugliano, M., Lonati, G., Rigamonti, L., 2007. Environmental release and mass flux partitioning of PCDD/Fs during normal and transient operation of full scale waste to energy plants. Chemosphere 67, S118-S124.

Kao, W.Y., Ma, H.W., Wang, L.C., Chang-Chien, G.P., 2007. Site-specific health risk assessment of dioxins and furans in an industrial region with numerous emission sources. J. Hazard Mater. 145, 471-481.

Kaufman, S.M., Themelis, N.J., 2009. Using a direct method to characterize and measure flows of municipal solid waste in the United States. J. Air Waste Manage. Assoc. 59, 1386-1390.

Kim, K.H., Chung, B.J., Lee, S.H., Seo, Y.C., 2008. Practices in dioxin emission reduction by special regulatory enforcement and utilizing advanced control technologies for incinerators in Korea. Chemosphere 73, 1632-1639.

Kollikkathara, N., Feng, H., Stern, E., 2009. A purview of waste management evolution: special emphasis on USA. Waste Manage. 29, 974-985.

Kulkarni, P.S., Crespo, J.G., Afonso, C.A.M., 2008. Dioxins sources and current remediation technologies - a review. Environ. Int. 34, 139-153.

Mari, M., Domingo, J.L., 2010. Toxic emissions from crematories: a review. Environ. Int. 36, 131-137.

MEDDTL, 2008. Spreadsheet with All Industrial Emissions of France, 2002-2008; Provided by Le ministère de l'Ecologie, du Développement Durable, des Transports et du Logement <www.developpement-durable.gouv.fr/> (This Spreadsheet Contains Nearly 60,000 Sets of Emission Data from all Industrial Sources in France for years 2002-2008. It is Available on Request to earth@columbia.edu).

Nadal, M., Schuhmacher, M., Domingo, J.L., 2004. Probabilistic human health risk of PCDD/F exposure: a socioeconomic assessment. J. Environ. Monit. 6, 926-931.

Olie, K., Vermeulen, P.L., Hutzinger, O., 1977. Chlorodibenzo-p-dioxins and chlorodibenzofurans are trace components of fly ash and flue gas of some municipal incinerators in the Netherlands. Chemosphere 6, 455-459.

Porteous, A., 2005. Why energy from waste incineration is an essential component of environmentally responsible waste management. Waste Manage. (Oxford) 25, 451-459.

Quass, U., Fermann, M., Breoker, G., 2004. The European dioxin air emission inventory project--final results. Chemosphere 54, 1319-1327.

Richter, S., Johnke, B., 2004. Status of PCDD/F-emission control in Germany on the basis of the current legislation and strategies for further action. Chemosphere 54, 1299-1302.

Schecter, A., Birnbaum, L., Ryan, J.J., Constable, J.D., 2006. Dioxins: an overview. Environ. Res. 101, 419-428.

Schuhmacher, M., Domingo, J.L., 2006. Long-term study of environmental levels of dioxins and furans in the vicinity of a municipal solid waste incinerator. Environ. Int. 32, 397-404.

Shibamoto, T., Yasuhara, A., Katami, T., 2007. Dioxin formation from waste incineration. Rev. Environ. Contam. Toxicol. 190, 1-41.

Singh, S., Prakash, V., 2007. Toxic environmental releases from medical waste incineration: a review. Environ. Monit. Assess. 132, 67-81.

Viel, J.F., Floret, N., Deconinck, E., Focant, J.F., 2011. Increased risk of non-Hodgkin lymphoma and serum organochlorine concentrations among neighbors of a municipal solid waste incinerator. Environ. Int. 37, 449-453.

Vilavert, L., Nadal, M., Figueras, M.J., Kumar, V., Domingo, J.L., 2011. Levels of chemical and microbiological pollutants in the vicinity of a waste incineration plant and human health risks: temporal trends. Chemosphere 84 (10), 14761483.

Wang, J.B., Hung, C.H., Hung, C.H., Chang-Chien, G.P., 2009. Polychlorinated dibenzo-p-dioxin and dibenzofuran emissions from an industrial park clustered with metallurgical industries. J. Hazard Mater. 161, 800-807.

USEPA, 2012. <http://cfpub.epa.gov/ncea/cfm/recordisplay.cfm?deid=15239>. 